\title{
Influence of physical activity on the life quality of teachers
}

\author{
JAROSLAV BROĎÁNI ${ }^{1}$; SVETLANA LIPÁROVÁ ${ }^{2}$ \\ ${ }^{1,2}$ University UKF, Constantine The Philosopher University in Nitra, Department of Physical Education and \\ Sport , SLOVAKIA
}

Published online: July 30, 2016

(Accepted for publication June 12 2016)

DOI:10.7752/jpes.2016.s1103

\begin{abstract}
:
The contribution presents the results of relation analysis between the frequency of physical activity during the week and fields of life quality of future teachers who are studying teaching in kindergartens and elementary schools, teachers who are already teaching in kindergartens, or teachers who teach in elementary schools in the first grade in Slovak republic. In the research took part teachers from Slovak republic $(n=322)$, who were divided into groups according ontogenetic aspect. Life quality was observed via modified questionnaire SQUALA and via the level of physical activity during the week concerning hours and the number of activities during the week. The data are presented by descriptive characteristics (n, M, SD) and by statistic importance of differences, let us say relations are regarded by non-parametric methods $\left(\mathrm{W}, \mathrm{U}, \mathrm{r}_{\mathrm{s}}\right)$ at levels of importance $(\mathrm{p}<, 05, \mathrm{p}<, 20)$.

The results showed the most numerous interactions between the physical activities during the week and the life quality areas at teachers in late adulthood who implement physical activities in M: 2.64-times per week at SD: 1,972 and by average number of M: $3.12 \mathrm{~h}, \mathrm{SD}: 2,52$. In the group were proved positive interactions with the area of physical well-being $(p<, 01)$, psycho-social well-being $(p<, 01)$, material well-being $(p<, 10)$, education $(p<, 10)$, free time $(p<, 20)$, appearance and possession of things $(p<, 05)$, let us say orientation to the future $(p<, 10)$. In the teacher groups in early and middle adulthood are not found any positive interactions between the physical activity and particular areas of life. The contribution is a part of grant MŠ SR KEGA 003UKF-4/2016. Key words: movement, life quality, interaction, teachers, kindergartens and elementary schools.
\end{abstract}

\section{Introduction}

Nowadays the life quality is a big trend. It is examined from different angles, different perspectives and different scientific fields. The evaluation of life quality and interference into it shows an improvement on the physical and mental signs and symptoms of the individual and also form a common research agenda. Research and theory supporting the need to assess the quality of life we find in medicine, psychiatry, clinical psychology, behavioral medicine and gerontology (Frisch, 1998).

For a proper evaluation of the quality of life and the well-designed questions, it is important to take into account the effects of disposal, adaptation, goals and coping strategies. It is also important to understand the interaction of psychological factors, living conditions, understand the cause of the road leading to happiness, to understand the process of elementary adaptation to events, and develop theories that explain why certain variables differently affect various components of the subjective perception of quality of life (Diener et al., 1999).

Physical activity presents many advantages in the cycle of life. However, the level of physical activity is lacking in many populations. Effective interventions to support or maintain the activity levels of young people are therefore crucial for public health (Van Sluijs \& Kriemler, 2016).

One of the research of Gonzala Silvetreho \& Ubilosa Landu (2016) considers physical activity as an important factor in assessing self-perception / self-awareness and life satisfaction. While physical self-perception and perceiving were proved to be the strongest factor in the effect of physical activity on the perception and evaluation of the quality of life by young women (18-45 years).By the physical activity Vancampfort et al. (2016) improved the quality of life even by people with bipolar disorder. It has been demonstrated that an active lifestyle reduces the risk and also the disease of the cardiovascular nature, and on the basis of the 10-questions the questionnaire and at the same time increased the quality of life by these people.

By the aerobic interval training Isaksen et al. (2016) affected the quality of life for people with coronary artery disease. There was showed a significant effect of physical activity on physical well-being of these people. Psychological well-being was not significantly changed compared to the baseline condition.

Multiple regression analysis showed that physical activity is an important indicator of the quality of life in young patients with cancer (Lam et al, 2016). The results provide further evidence that cancer and its treatment has a negative impact on physical and mental well-being and quality of life among patients. Health 
care workers should promote regular physical activity among these patients, and even during the actual treatment.

Low level of physical activity and quality of life was recorded even by wheelchair patients. Just focusing and promotion of the physical activity and employment improved the perception of the quality of life for this group of people in the age of middle adulthood (Ganesh \& Mishra, 2016). Scogin et al. (2016) figured out, that the involvement of people in pleasant events as well as inducing state of hopelessness affects quality of life positively. The research was done on an earlier adulthood in rural settlements. This rural population had reduced quality of life and also negative psychological symptoms

Weeks at all. (2004) and Lee \& Lassey (1980) compared the life of the older population in rural settlements and in suburban and urban areas. The rural population had, although a better physical well-being, or physical health, but worse for it to be with mental well-being. Quality of life from the perspective of mental health has the population living in cities or in suburban parts, where they have more options for social and cultural life.

Research that observed the quality of life by teachers in primary and nursery schools, adulthood studying in this department as well as pupils in primary and secondary schools are mostly from the Slovak authors (Brod’áni et al., 2015; Brod’áni \& Žišková, 2014; Brod'áni \& Špániková, 2013; Kalinková et al., 2015; Pašková, 2010; Romanová \& Sollár, 2015; Sýkora \& Blatný, 2008;). These are works that deal with the interaction of physical activity and quality of life, i.e. a positive influence of physical activities on mental and physical health of individuals in the different age periods as well as positive action on the personal experience and the perception of the human.

We contribute with our work to the extension of a research/study the sample of teachers and potential teachers of the first stage of elementary schools and kindergartens and their view of their own quality of life. We have been interested in particular relationship between the personal well-being and physical activities, which tested were carried out in a certain range and frequency during the week. We expected a higher number of significant relationships with the areas of quality of life in the groups with higher reference to being physically active in the week. As one with the significant factors, which should affect the aforementioned causality at all in relation to the result, are ontogenetic periods of adulthood.

\section{Methodology}

The questionnaire survey which was aimed at determining the frequency of physical activity in the week, the sports level and quality of life participated the future teachers studying teaching in nursery schools and teacher training the first stage of elementary schools, teachers in nursery schools, or teachers teaching at the first grade in primary schools in Slovak republic $(n=322)$. The average age of the group was M: 35,79 year with directive deviation SD: 13,215 (Max 20, Min 66 years).

The research file was approximately divided according to Pokorná (2010) into three groups into groups according to ontogenetic terms: younger adulthood (20-35 years), middle adulthood (B 36-46 years) and late adulthood (C 47 to 62 years), see tab. 1 and 2.

A modified questionnaire for teachers according to the authors (Dragomerická, 2006; Ocetková, 2007; Sýkorová \& Blatný, 2008; Zannotti - Pringuey, 1992) contained selected items from SQUALA. SQUALA entries were evaluated in terms of areas:

1. Physical well - being (health, sleep, handle everyday activities, not having problems);

2. Psycho - social well - being (family, relationships, intimate relations, hobbies, safety);

3. Spiritual well - being (justice, freedom, beauty, art, truth);

4. Material well - being (money, good food);

5. Education (to be educated, attend school);

6. Free time (possibilities to spend free time, have enough items for entertainment);

7. Appearance and possession of things (look good, wear nice things, own things I like);

8. Orientation to the future (have children in the future, job I will enjoy).

The questionnaire defines the area of objective site, "How important is it for you ...." and the second from the subjective side "How satisfied are you with ....".

Both items assessed the respondents on a 5-point scale depending on what the meaning of her life placed, or how important it has been for them in their life (1. Completely unimportant, 2. Somewhat important, 3. Moderately important 4. Very important 5. Quite important), and (1. Very dissatisfied, 2. Dissatisfied, 3. Something in between, 4. Satisfied, 5. Very satisfied).

When processing data, we used the basic descriptive statistics (frequency $\mathrm{n}$, diameter $\mathrm{M}$, standard deviation SD). Differences between importance and satisfaction in the quality of life for dependent groups, were assessed by Wilcoxon's z test, and differences between independent groups were assessed by the Mann-Whitney $\mathrm{U}$ test. When calculating the interaction between the variables "refer to being physically active during the week and the area of the quality of life", we used the Spearman's correlation coefficient $\left(r_{s}\right)$.

For the assessment of the statistical significance we used the level of significance $p<0,05$ and relations $\mathrm{p}<0,20$. The data were handled in programmes MS Excel a SPSS. 


\section{Results and discussion}

Physical activity of teachers in individual ontogenetic-groups in adulthood is differentiated from the perspective of frequency as well as volume of physical activities in a week (table 1 and 2). The highest level of hourly volume of physical activities in the week shows a group of future teachers in the early adulthood (M: 6,56 h; SD: 4,30), with an average age 25,31 year. With the increasing age of teachers it is reduced, the frequency of physical activities as well as the amount of hours. The lowest physical activity in the week was recorded in late adulthood (M: 3,12 h; SD: 2,52), in the group of teachers with a higher average age (M: 53,97, SD:5,49).

With the declining age is the ratio of completed hours to the number of implemented physical activities in the week higher. The highest ratio was logically recorded in the group of teachers in early adulthood (A: 1,39 $\mathrm{h} / \mathrm{n}$ ). For teachers in the middle and late adulthood is the ratio of the hours and the number of physical activities in the week at the same level B: $1,17 \mathrm{~h} / \mathrm{n}: 1,18 \mathrm{~h} / \mathrm{n}(\mathrm{p}=\mathrm{s} . \mathrm{n})$.

Personal evaluation of the areas of the quality of life of teachers in groups in the early, middle and late adulthood in most cases is at the same level (tab. 1 and 2). From the point of importance, we find differences only in the area of free time $(\mathrm{p}<, 05)$, let us say in the area of appearance and possession of things $(\mathrm{p}<, 01)$. The teachers in the group of younger adulthood in both cases, they attach to these areas higher importance than teachers in late adolscence. Similarly, is a group of the youngest teachers more satisfied with physical well-being $(\mathrm{p}<, 05)$, education $(\mathrm{p}<, 05)$ and free time area $(\mathrm{p}<, 05)$. The oldest teachers are satisfied with the area of future $(\mathrm{p}<, 05)$ than the youngest teachers.

Table 1 The comparison of age, physical activity during the week and fields of life quality between the age groups of teachers

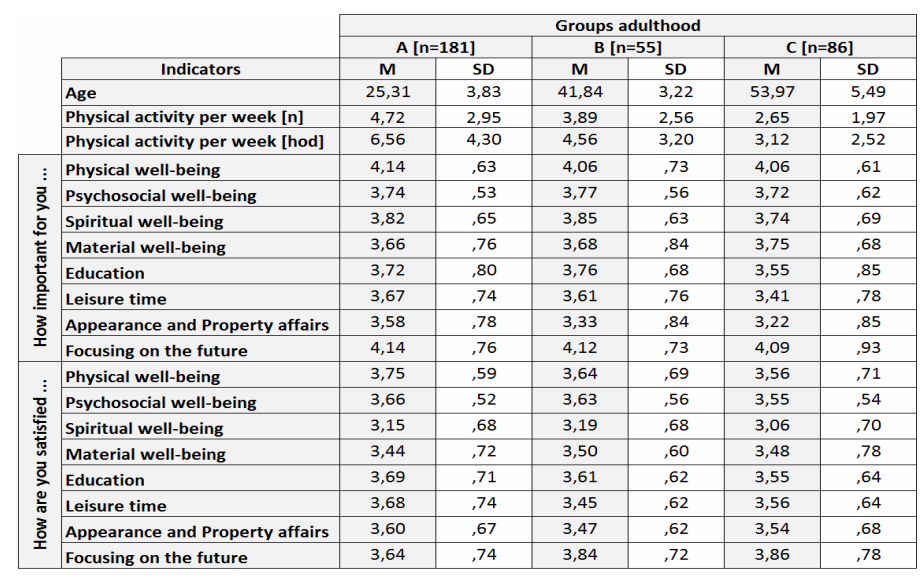

Table 2 Statistic comparison of age, physical activity during the week and fields of life quality between the age groups of teachers (Mann Whitney U-test; $\mathbf{p}<\mathbf{0 , 0 1 * * ;} \mathbf{p}<\mathbf{0 , 0 5 *}$ )

\begin{tabular}{|c|c|c|c|c|c|c|c|}
\hline \multirow{2}{*}{\multicolumn{2}{|c|}{\begin{tabular}{|l} 
Indicators \\
\end{tabular}}} & \multicolumn{2}{|c|}{$A \ll B$} & \multicolumn{2}{|c|}{$B \ll C$} & \multicolumn{2}{|c|}{$A \leftrightarrow C$} \\
\hline & & d & p-value & d & p-value & d & p-value \\
\hline & Age & 16,53 & $0,000^{* *}$ & 12,13 & $0,000 * *$ & 28,66 & $0,000 * *$ \\
\hline & Physical activity per week [n] & $-0,83$ & 0,055 & $-1,24$ & $0,001^{* *}$ & $-2,07$ & $0,000^{* *}$ \\
\hline & Physical activity per week [hod] & $-2,00$ & $0,002 * *$ & $-1,45$ & $0,002 * *$ & $-3,45$ & $0,000 * *$ \\
\hline \multirow{8}{*}{ 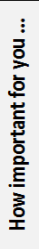 } & Physical well-being & $-0,08$ & 0,510 & 0,00 & 0,885 & $-0,08$ & 0,277 \\
\hline & Psychosocial well-being & 0,03 & 0,949 & $-0,05$ & 0,909 & $-0,01$ & 0,887 \\
\hline & Spiritual well-being & 0,02 & 0,924 & $-0,11$ & 0,361 & $-0,08$ & 0,292 \\
\hline & Material well-being & 0,02 & 0,945 & 0,07 & 0,610 & 0,09 & 0,437 \\
\hline & Education & 0,04 & 0,958 & $-0,22$ & 0,173 & $-0,17$ & 0,107 \\
\hline & Leisure time & $-0,06$ & 0,650 & $-0,20$ & 0,139 & $-0,26$ & $0,012^{*}$ \\
\hline & Appearance and Property affairs & $-0,25$ & 0,102 & $-0,11$ & 0,333 & $-0,36$ & $0,001^{* *}$ \\
\hline & Focusing on the future & $-0,02$ & 0,730 & $-0,03$ & 0,781 & $-0,05$ & 0,960 \\
\hline \multirow{8}{*}{ 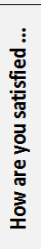 } & Physical well-being & $-0,11$ & 0,179 & $-0,09$ & 0,530 & $-0,20$ & $0,033^{*}$ \\
\hline & Psychosocial well-being & $-0,03$ & 0,637 & $-0,08$ & 0,279 & $-0,11$ & 0,054 \\
\hline & Spiritual well-being & 0,04 & 0,732 & $-0,13$ & 0,214 & $-0,08$ & 0,173 \\
\hline & Material well-being & 0,06 & 0,641 & $-0,02$ & 0,842 & 0,04 & 0,808 \\
\hline & Education & $-0,08$ & 0,302 & $-0,06$ & 0,613 & $-0,13$ & $0,049 *$ \\
\hline & Leisure time & $-0,23$ & $0,016^{*}$ & 0,10 & 0,474 & $-0,12$ & 0,055 \\
\hline & Appearance and Property affairs & $-0,14$ & 0,135 & 0,07 & 0,583 & $-0,07$ & 0,356 \\
\hline & Focusing on the future & 0,20 & 0,123 & 0,02 & 0,603 & 0,22 & $0,014^{*}$ \\
\hline
\end{tabular}

Teachers give greater importance in most cases to the individual areas of quality of life as they are satisfied with them (picture 1 - 3). They consider to be very important the physical well-being $(\mathrm{M}: 4,06-4,14)$, orientation to the future (M: 4,09-4,14), spiritual well-being (M: 3,74-3,85) and the psychosocial well-being (M: $3,72-3,77)$. They attach the lowest importance to teacher's appearance, possession of things, free time. The satisfaction of teachers with the areas of quality of life in all ontogenetic groups moves to the lower boundary of 
the satisfaction. The lowest satisfaction is reported with the area of spiritual well-being (M: 3,06-3,19).The highest values of satisfaction were proved in the area of orientation to the future among teachers in medium (M: 3,84) and late adulthood (M: 3,86). Among teachers in the younger adulthood, in turn, with the area of physical well-being (M: 3,75). Evaluation of satisfaction with the remaining fields of the life quality varies in average between 3,44 - 3,68.

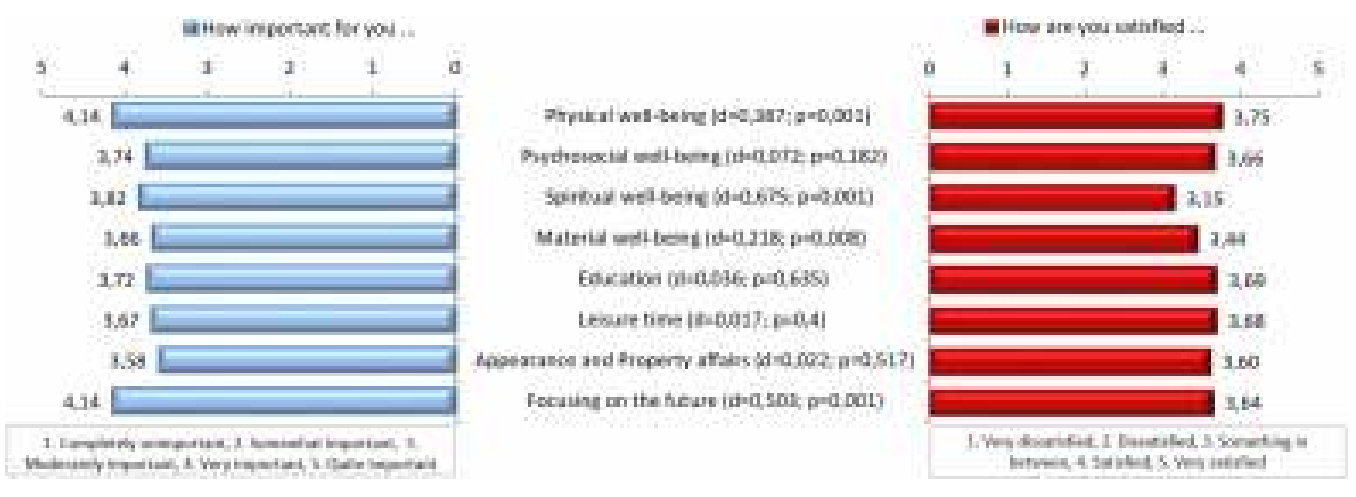

Graph 1 Statistic comparison of particular fields of life quality from the point of importance and satisfaction in the group of adults - A early adulthood $(z ; p<0,05)$
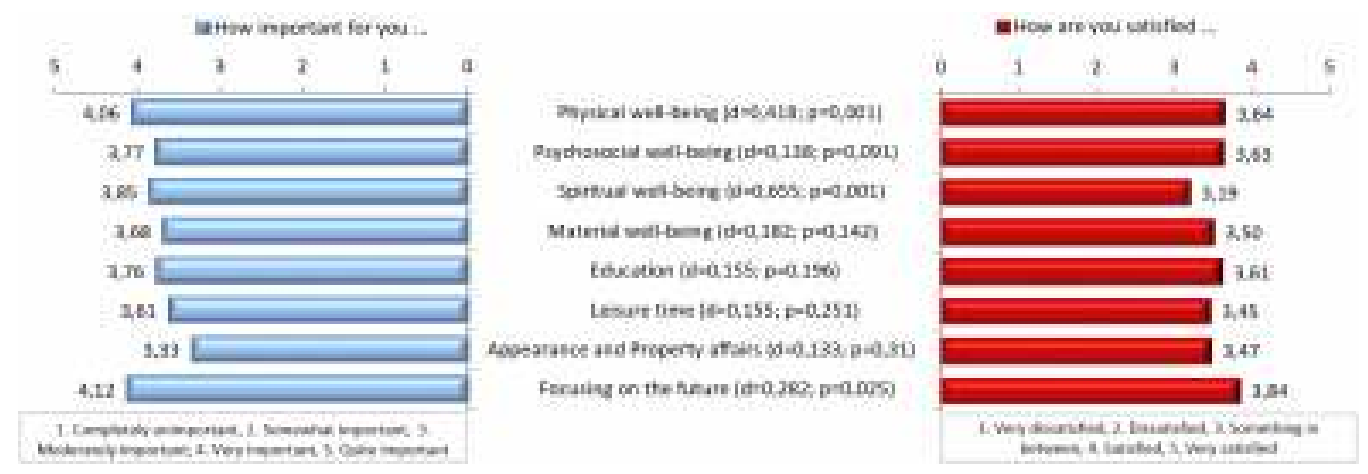

Graph 2 Statistic comparison of particular fields of life quality from the point of importance and satisfaction in the group of adults $-\mathrm{B}$ middle adulthood $(\mathrm{z} ; \mathrm{p}<0,05)$
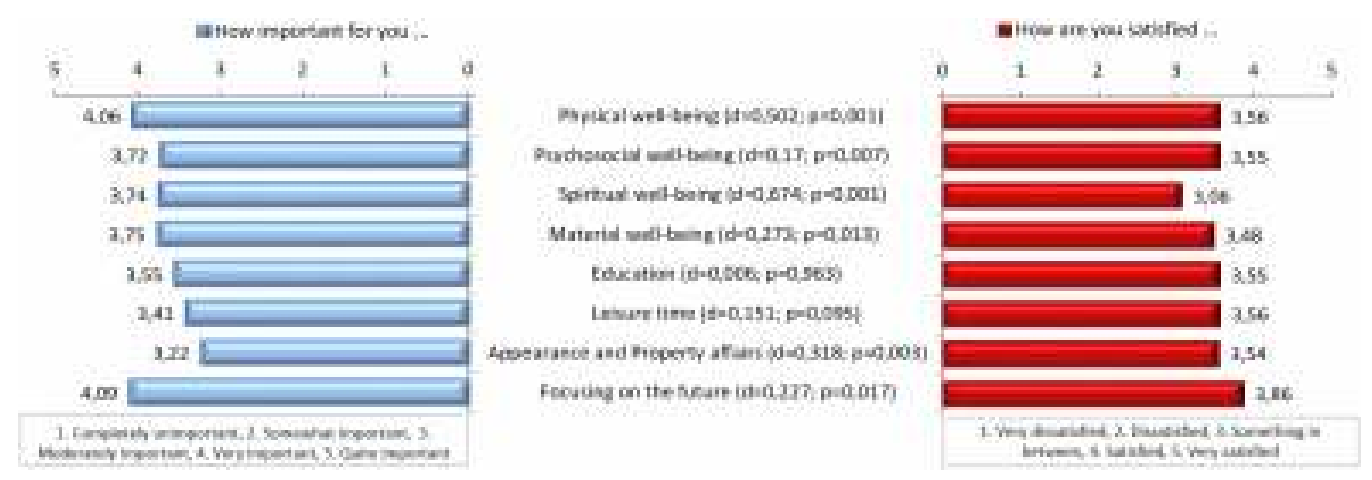

Graph 3 Statistic comparison of particular fields of life quality from the point of importance and satisfaction in the group of adults $-\mathrm{C}$ late adulthood $(\mathrm{z} ; \mathrm{p}<0,05)$

From the point of the evaluation of the life quality, however, has for us a greater importance personal evaluation of satisfaction with the various areas of life quality, which we have used in the searching for interactions with physical activity in a week expressed in hours.

The correlation analysis showed the largest interactions between being physically active during the week and those areas of the life quality for teachers in late late adulthood (table 3 ). Teachers in late adulthood performed physical activity in the average M: 2,64 times a week in SD: 1,97 and in the average number of hours $\mathrm{M}: 3,12 \mathrm{~h}, \mathrm{SD}: 2,52$. In the group were proven positive interactions with the area of physical well-being $(\mathrm{p}<, 01)$, psycho-social well-being $(\mathrm{p}<, 01)$, material well-being $(\mathrm{p}<, 10)$, education $(\mathrm{p}<, 10)$, free time $(\mathrm{p}<, 20)$, appearance 
and possession of things $(\mathrm{p}<, 05)$, if you like orientation to the future $(\mathrm{p}<, 10)$. In the groups of young and middle adulthood were not found positive either negative interactions between the physical activity and particular fields of life quality.

Table 6 Frequency correlations of physical activity during the week and particular fields of life quality in the groups of teachers (Spearman correlation coefficient $r_{s} ; p<0,20^{*} ; p<0,10^{* *} ; p<0,05^{* * *} ; p<0,01^{* * * *}$ )

\begin{tabular}{|c|c|c|c|c|c|}
\hline & & & \multicolumn{3}{|c|}{ Groups adulthood } \\
\hline & & & A & B & C \\
\hline \multirow{16}{*}{ 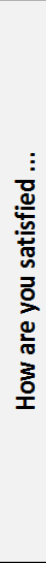 } & \multirow{2}{*}{ Physical well-being } & $r_{s}$ & ,064 & ,012 & $0,208 * * *$ \\
\hline & & $p$ value & ,392 & ,931 & 055 \\
\hline & \multirow{2}{*}{ Psychosocial well-being } & $r_{s}$ & ,037 & ,088 & $0,323 * * * *$ \\
\hline & & p value & ,618 &, 522 &, 002 \\
\hline & \multirow{2}{*}{ Spiritual well-being } & $r_{s}$ & ,082 & ,091 & ,031 \\
\hline & & p value & ,272 &, 509 & ,780 \\
\hline & \multirow{2}{*}{ Material well-being } & $r_{s}$ &,- 015 & ,128 & $0,187 * *$ \\
\hline & & p value & ,839 & ,353 & 085 \\
\hline & \multirow{2}{*}{ Education } & $r_{s}$ & ,039 &,- 062 & $0,184 * *$ \\
\hline & & p value & ,605 & ,654 & 091 \\
\hline & \multirow{2}{*}{ Leisure time } & $r_{s}$ & ,024 & ,027 & $0,173^{*}$ \\
\hline & & p value & ,753 & ,847 & ,112 \\
\hline & \multirow{2}{*}{$\begin{array}{l}\text { Appearance and } \\
\text { Property affairs }\end{array}$} & $r_{s}$ & ,074 & ,085 & $0,227 * * *$ \\
\hline & & p value & ,322 & ,539 &, 035 \\
\hline & \multirow{2}{*}{ Focusing on the future } & $r_{s}$ &,- 039 & ,069 & $0,186 * *$ \\
\hline & & p value & ,599 & ,616 &, 086 \\
\hline
\end{tabular}

The same research methods were applied to the groups of future teachers and teachers in the Slovak republic. It turns out that the period of middle and late adulthood is the most perceptive period of self-awareness of the quality of life and the need for regular physical activity, and their mutual interrelationship. The quality of life and physical activities while they act as two separate entities must be inside homogeneous. It is confirmed by several works, which show the interaction of individual areas of quality of life in different physical activity in a week. The results are differentiated with respect to age and amount of physical activity in a week.

In the work Brod’áni \& Žišková (2014) were by female teachers in the age group of 36-46 years (middle adulthood) recorded positive interactions with the area of physical well-being, psychosocial well-being, material well-being,, education, leisure time, appearance and possession of things when the average physical activity during the week M: 3,250 hours SD: 2,761.

Numerous - positive correlations between the physical activity during the week and those areas of life quality recorded by female teachers in primary school years 1-4 (Brod'áni et al., 2015), at which the physical activity carried out in the week in the M: 4,651 in SD 1,021. 42-year-old female teachers were proved positive correlations with the area of physical well-being, psychosocial well-being, spiritual and material well-being, let us say free time.

Brod'áni and Špániková (2013) mention in a group of 22 year old female teachers, who performed physical activity 3-4 times per week a positive interaction with the areas of physical and material well-being, or appearance and possession of things. One of the factors which significantly affected the positive interaction was a pleasure from the performed physical activity (Sollár \& Romanová, 2015; Romanová\& Sollár, 2015).

\section{Conclusions}

There is a lot of empirical evidence that physical health is closely linked with physical activity. Physical activity carried out with the pleasure and by own will is a determinant of participation in physical activity and remaining in it. The optimal level of physical activity during the week significantly corresponds with the areas of life quality exactly for such a population.

Our conclusions also point to the importance of physical activity in life by a specific group of adults. It turned out that physical activity by teachers in the late adulthood implemented in the week on average, M: 2,64 times in the SD: 1,972, and the average number of hours M: 3,12 $\mathrm{h}$ for SD: 2,52, was sufficient to identify significant engagement with areas of life quality.

The empirical knowledge that adults with higher physical activity during the week have a higher number of interactions with the areas of quality of life was not proved. It is a paradox that right in the period of early and middle adulthood, which are characteristic by the achievement of the highest peak of physical and mental performance, with self-awarened perception of both appreciation of the life quality and the need for regular physical activity, and their mutual interrelationship, have not recorded any significant relationships.

In connection with this result is needed the following research of specific groups of adult teachers who can offer us a more proper view on the problematic from the point of searching relations between the physical activities and fields of life quality. 


\section{References}

Brod'áni, J., Špániková, V. (2013). Kvalita života vo vzt’ahu k frekvencii pohybovej aktivity v týždni u študentiek PEP a UPV na PF UKF v Nitre. Slovak journal of sports science, 5(1), 86-95.

Brod'áni, J. \& Žišková, I. (2015). Quality of life and physical activity of kindergarden teachers. Physical Activity Review, 3(1), 11-20.

Brod’áni, J., Paška, L., Kalinková, M., Šutka, V., Matasová, Z. (2015). The frequency of physical activity during the weekin relation to thequality of life of teachers in the first grade at primary schools. Sport Science. 8(1/2), 39-43.

Diener, Ed., Suh, E.M., Lucas, R.E., Smith, H.L. (1999). Subjective well-being: Three decades of progress. Psychological Bulletin. 125(2), pp. 276-302

Dragomirecká, E. (2006). SQUALA Subjective quality of life analysis : příručka pro uživatele české verze dotazníku subjektivní kvality života SQUALA. Praha : Psychiatrické Centrum.

Frisch, M. B. (1998). Quality of life therapy and assessment in healthcare. In Clinical Psychology: Science and Practice. 5(1), 19-40.

Ganesh, S., Mishra, C. (2016). Physical activity and quality of life among adults with paraplegia in Odisha, India. Sultan Qaboos University Medical Journal. 16(1), 54-61.

Gonzalo Silvestre, T., Ubillos Landa, S. (2016). Women, Physical Activity and Quality of Life : Self-conceptas a Mediator. Spanish J of Psychology. Feb 22; 19 : E6. doi: 10.1017/sjp.2016.4.

Isaksen, K., Munk, P.S., Giske, R., Larsen, A. I. (2016). Effects of aerobic interval training on measures of anxiety, depression and quality of life in patients with ischaemic heart failure and an implantable cardioverter defibrillator: A prospective non-randomized trial. Journal of Rehabilitation Medicine. 48(3), 300-306.

Kalinková, M., Paška, L., Brod’áni, J., Orlíková, M. (2015). Vplyv pohybu na životný štýl a kvalitu života učitel'ov primárneho vzdelávania. Vplyv pohybu na kvalitu života človeka a jeho životný štýl.(pp.147 156). Nitra, Slovakia: PF UKF.

Lam, K.K.W., Li, W.H.C., Chiu, S.Y., Chan, G.C.F. (2016). The impact of cancer and its treatment on physical activity levels and quality of life among young Hong Kong Chinese cancer patients. European Journal of Oncology Nursing. 21:83-9. doi: 10.1016/j.ejon.2016.01.007.

Lee, G.R.,Lassey, M.L. (1980). Rural-urban differences among the elderly: economic, social and subjective factors. Journal of Social Issues. 36(2), 62-74.

Ocetková, I. (2007). Úloha spirituality v životní pohodě a kvalite života mladých lidí. (Dizertačná práca). Brno : Masarykova univerzita.

Pašková, L. (2010). Vzt’ah telesnej aktivity a subjektívnej pohody u vysokoškolských študentov. Studia kinanthropologica, 9(2), 77-82.

Romanová, M., Sollár, T. (2015). Úroveň športovej aktivity, užívanie návykových látok a radost' z pohybovej aktivity v období adolescencie a ranej dospelosti. In Pohyb a kvalita života 2015. (pp. 126-131). Nitra, Slovakia : UKF.

Scogin, F., Morthland, M., Dinapoli, E.A., Larocca, M.,Chaplin, W. (2016). Pleasant Events, Hopelessness, and Quality of Life in Rural Older Adults. Journal of Rural Health. 32(1), 102-109.

Sollár, T., Romanová, M. (2015). Vývinové špecifiká a rodové rozdiely v radosti z pohybovej aktivity v období adolescencie a ranej dospelosti In: Pohyb a kvalita života 2015. (pp. 78-82). Nitra, Slovakia : UKF.

Sýkorová, Z. \& Blatný, M. (2008). Kvalita života u adolescentov. Brno: Masarykova univerzita.

Vancampfort, D., Rosenbaum, S., Probst, M., Connaughton, J., DuPlessis, C., Yamamoto, T., Stubbs, B. (2016). Top 10 research questions to promote physical activity in bipolar disorders: A consensus statement from the International Organization of Physical Therapists in Mental Health. Journal of Affective Disorders. 195:82-7. doi: 10.1016/j.jad.2016.01.046.

Van Sluijs, E.M.F., Kriemler, S. (2016). Reflections on physical activity intervention research in young people dos, don'ts, and critical thoughts. International Journal of Behavioral Nutrition and Physical Activity. 13(1):25. doi: 10.1186/s12966-016-0348-z.

Weeks, W.B., Kazis, L.E., Shen, Y., Cong, Z., Ren, X.S., Miller, D., Lee, A., Perlin, J.B. (2004). Differences in health-relatedqualityoflife in rural and urbanveterans. American Journal of Public Health. 94(10), $1762-1767$

Zannotti, M. \& Pringuey, D. (1992). A method for quality of life assessment in psychiatry: the S-QUA-L-A (Subjective Quality of life Analysis). Quality of life News Letter, 4(6). 